\title{
Pengelolaan Hipertermi pada Anak Dengan Riwayat Kejang Demam Sederhana di Desa Krajan Banyubiru
}

\author{
Siti Nur Aziza ${ }^{1}$, Eka Adimayanti ${ }^{2}$ \\ ${ }^{1,2}$ Prodi D3 Keperawatan Fakultas Kesehatan Universitas Ngudi Waluyo \\ Email: saziza531@gmail.com
}

\begin{abstract}
ABSTRAK
Kejang demam adalah bangkitan kejang yang terjadi akibat peningkatan suhu tubuh melebihi batas normal akibat proses ekstrakranial. Kejang demam sederhana yaitu kejang demam yang terjadi tidak lebih dari 15 menit dan tidak berulang selama 24 jam. Pasien dengan kejang demam mempunyai gejala demam tinggi atau hipertermi. Hipertermi adalah meningkatnya suhu tubuh melebihi batas ambang normal. Tujuan penulisan ini untuk menggambarkan Pengelolaan Hipertermi Pada Anak Dengan Riwayat Kejang Demam Sederhana Di Desa Krajan Banyubiru.Metode yang digunakan deskriptif dengan pendekatan studi kasus melalui asuhan keperawatan yang terdiri dari pengkajian, intervensi keperawatan, implementasi keperawatan dan evaluasi keperawatan. Pengelolaan hipertermi dilakukan dengan memonitor tanda-tanda vital, monitor asupan cairan, melakukan pendinginan eksternal, melonggarkan pakaian, mengkolaborasikan pemberian terapi farmakologi serta melakukan pemeriksaan laboratorium. Hasil pengelolaan yang didapatkan dengan intervensi yang telah dirancang adalah pasien mengalami penurunan suhu tubuh hingga kembali ke normal. Hal ini membuktikan bahwa tindakan yang dilakukan berdasarkan intervensi berhasil sehingga masalah hipertermi dapat teratasi. Saran bagi keluarga agar lebih mengetahui bagaimana cara penanganan demam pada anak dan mampu mencegah terjadinya kejang berulang.
\end{abstract}

\section{Kata kunci : Hipertermi, Anak, Kejang Demam}

\begin{abstract}
Management of hyperthermia in children with a history of simple febrile seizures in the village of Krajan Banyubiru

Febrile seizures is seizures that occur due to an increase in body temperature that exceeds normal limits due to extracranial processes. A simple febrile seizure is a febrile seizure that lasts no more than 15 minutes and does not recur for 24 hours. Patients with febrile seizures have symptoms of high fever or hyperthermia. Hyperthermia is an increase in body temperature beyond the normal threshold. The purpose of this paper is to describe the management of hyperthermia in children with simple febrile seizures in the village of Krajan Banyubiru. The method used is descriptive with a case study approach through nursing care which consists of assessment, nursing intervention, nursing implementation and nursing evaluation. Management of hyperthermia is carried out by monitoring vital signs, monitoring fluid intake, performing external cooling, loosening clothing, collaborating with pharmacological therapy and conducting laboratory tests.The results of the
\end{abstract}

Pengelolaan Hipertermi Pada Anak... Siti Nur Aziza, Eka Adimayanti Journal of Holistics and Health Sciences Vol. 3, No. 2 September 2021 
management obtained with the intervention that has been designed are that the patient experiences a decrease in body temperature until it returns to normal. This proves that the actions taken based on the intervention are successful so that the hyperthermia problem can be resolved. Suggestions for families to know more about how to handle fever in children.

\section{Keywords : Hyperthermia, Child, Febrile Seizure}

\section{PENDAHULUAN}

Sehat adalah keadaan dimana kesejahteraan dalam keadaan optimal antara fisik, mental dan sosial yang perlu dicapai selama kehidupan. Kondisi sehat dalam rangka pencapaian tingkat pertumbuhan dan perkembangan yang optimal sesuai dengan usia anak (Supartini, 2014). Masalah kesehatan anak diprioritaskan dalam perencanaan atau penataan pembangunan dan upaya pemeliharaan kesehatan (Hidayat, 2012). Kualitas anak merupakan penentu kualitas sumber daya manusia dimasa yang akan datang. Masa depan manusia perlu dipersiapkan, agar anak mampu tumbuh dan berkembang seoptimal mungkin sesuai dengan kemampuannya (Esyuananik, 2016). Ketika kondisi kesehatan anak kurang sehat, akan berdampak pada berbagai hal yang berkaitan dengan perkembanganya dan terhadap berbagai aktivitas yang akan dilakukannya (Awaluddin \& Dkk, 2017).

Salah satu masalah kesehatan yang terjadi pada anak di Indonesia adalah kejang demam. Kejang demam adalah bangkitan kejang yang terjadi pada kenaikan suhu tubuh rektal lebih dari $38^{\circ} \mathrm{C}$ akibat proses ekstra kranial (Deliana, 2016). World Health Organization memperkirakan terdapat lebih dari 21,65 juta penderita kejang demam dan lebih dari 216 ribu diantaranya meninggal dunia dengan usia antara 1 bulan sampai 11 bulan (WHO, 2018). Prevalensi demam di Asia dilaporkan lebih tinggi sekitar $80 \%$ sampai $90 \%$ dari seluruh kejang demam yang terjadi di dunia. Angka kejadian kejadian kejang demam di Indonesia dilaporkan sekitar 14.252 penderita (Kemenkes RI, 2019). Provinsi Jawa tengah mencapai $2 \%$ sampai $3 \%$, angka kejadian kejang demam, sekitar $2 \%$ sampai $5 \%$ terjadi pada anak usia 6 bulan sampai 5 tahun (Indrayati \& Haryanti, 2019). Hasil wawancara yang dilakukan dengan Bidan Sri Harti Banyubiru menyatakan bahwa selama satu tahun terakhir angka kejadian kejang demam terdapat 10 orang 4 diantaranya terjadi pada anak usia 1- 5 tahun dan 3 diantaranya terjadi pada usia bayi 0-12 bulan.

Kejang demam merupakan kelainan neurologis yang paling sering ditemukan pada anak terutama rentang usia 6 bulan sampai 5 tahun. Kejang demam merupakan gangguan transien pada anak-anak yang terjadi bersama dengan demam, anak dengan kejang rendah terjadi pada suhu tubuh $38^{\circ} \mathrm{C}$ tetapi anak dengan ambang kejang tinggi kejang baru akan terjadi pada suhu $40^{\circ} \mathrm{C}$ atau bahkan lebih (Sodikin, 2012). Penyebab anak mengalami kejang demam masih belum dapat dipastikan, faktor pencetus kejang demam bukan pada saat setelah terjadi kenaikan suhu yang lama, melainkan pada saat suhu tubuh mengalami kenaikan yang disebut hipertermi (Sodikin, 2012). Hipertermi adalah suhu tubuh 
meningkat diatas rentang normal tubuh (PPNI, 2017).

Penatalaksanaan hipertermi menurut Indijah \& Fajri, 2016 terdapat dua jenis yaitu penatalaksanaan medis dan penatalaksanaan keperawatan. Penatalaksanaan medis yang diberikan kepada pasien dengan hipertermi adalah dengan memberikan terapi farmakologi antibiotik dan antipiretik. Penatalaksanaan keperawatan hipertermi menurut wong, 2012 yaitu berikan selimut pendingin atau matras, berikan mandi kompres dengan durasi 20-30 menit, berikan handuk atau waslap dingin pajankan area tubuh satu per satu, ganti sesuai kebutuhan, hindari menggigil, jangan pernah menggunakan usapan isopropil alkohol saat mandi atau kompres karena dapat menyebabkan efek neurotoksik, dan panatau suhu tubuh untuk mencegah terjadinya kedinginan. Penelitian lain yang dilakukan oleh (Haryani, Adimayanti, \& Astuti 2018) tentang Pengaruh tepid sponge terhadap penurunan suhu tubuh pada anak pra sekolah menyebutkan bahwa pemberian kompres water tepid sponge berpengaruh terhadap penurunan suhu tubuh pasien dengan mean differene $1^{\circ} \mathrm{C}$.

Berdasarkan data diatas, penulis tertarik untuk melakukan Pengelolaan Hipertermi Pada Anak Dengan Riwayat Kejang Demam Sederhana Di Desa Krajan Banyubiru.

\section{METODE}

Metode yang digunakan adalah deskriptif dengan studi kasus , dimana penulis menggali kasus dalam waktu dan kegiatan dengan mengumpulkan data secara teperinci menggunakan prosedur teknik wawancara, observasi serta pengkajian fisik secara langsung kepada pasien. Adapun kriteria subyek pengelolaan meliputi pasien dengan kategoria usia bayi, pasien yang mengalami demam tinggi disertai kejang, pasien dengan kesadaran composmentis, pasien dan keluarga mampu berkomunikasi secara verbal serta koooperatif, bersedia untuk dijadikan responden dan menyetujui hal tersebut. Pada pengelolaan kasus hipertermi pada anak dengan riwayat kejang demam sederhana di desa krajan banyubiru dilakukan selama 3 hari, dengan teknik pengumpulan data melalui proses asuhan keperawatan meliputi, pengkajian, merumuskan diagnosa, intervensi keperawatan, implementasi keperawatan dan evaluasi keperawatan.

\section{HASIL}

Pengkajian dilakukan pada pasien dengan hipertermi riwayat kejang demam sederhana di desa Krajan Banyubiru pada hari Selasa, 2 Februari 2021 dengan metode allowanamnesa yang dilakukan dengan wawancara ibu pasien. Pasien adalah anak usia 9 bulan 24 hari dengan keluhan utama didapatkan data subyektif yaitu ibu pasien mengatakan bahwa anaknya demam sudah 1 hari disertai kejang \pm 2 menit pada pukul 08.30 WIB. Data obyektif yang didapatkan S: $38,4^{\circ} \mathrm{C} \quad \mathrm{N}: 120$ $\mathrm{x} /$ menit, RR : $22 \mathrm{x} /$ menit, kulit pasien tampak kemerahan dan akral hangat, pasien rewel dan menangis. Hasil pemeriksaan laboratorium pasien yaitu hemoglobin 13,2 g/dl, MCHC $35,9 \%$, dan monosit sebesar 6,8.

Tindakan keperawatan yang telah diberikan saat pasien periksa adalah memonitor suhu tubuh, 
melakukan pendinginan eksternal, berkolaborasi dalam pemberian obat penurun panas, pasien dilakukan pengambilan darah untuk pemeriksaan laboratorium di Puskesmas Banyubiru pada 2 Februari 2021 dengan hasil hemoglobin 13,2 g/dl, MCHC 35,9\%, monosit 6,8. Hasil pengkajian yang telah dilakukan kemudian dilakukan analisisa data. Data subjektif yang didapatkan yaitu ibu pasien mengatakan anaknya demam sudah 1 hari disertai kejang \pm 2 menit pada 08.30 WIB, ibu pasien mengatakan tidak mengetahui cara untuk penanganan kejang demam pada anak. Data obyektif yang didapatkan dari pengkajian yaitu suhu $38,4^{\circ} \mathrm{C}$, nadi $120 \mathrm{x} / \mathrm{menit}$, respirasi $22 \mathrm{x} / \mathrm{menit}$, kulit kemerahan, akral hangat, mukosa bibir pucat, bising usus 20x/menit, pasien tampak rewel, pasien sering menangis, dan ibu pasien tampak cemas akan kondisi anaknya. Dari analisa data yang tersebut dapat ditegakkan diagnosa utama yaitu Hipertermi berhubungan dengan proses penyakit (D.0130).

$$
\text { Intervensi }
$$

disusun

berdasarkan prioritas masalah yang dialami oleh pasien. Prioritas penanganan pada pasien kejang demam sederhana dengan masalah keperawatan hipertermi adalah mengoptimalkan suhu badan menjadi normal dimana penanganan ini berdasarkan manajeman hipertermi (I.15506). Tujuan dari intervensi yang telah disusun adalah setelah dilakukan tindakan keperawatan selama 3x24 jam masalah hipertermi membaik dengan kriteria hasil berpedoman dari termoregulasi (L.14134).

\begin{tabular}{lccr} 
& \multicolumn{2}{c}{ Implementasi } & dilakukan \\
selama & 3 & hari & kelolaan. \\
Impelementasi & hari & pertama
\end{tabular}

dilakukan pada Selasa, 2 Februari 2021 yaitu mengukur suhu tubuh dengan menggunakan termometer axilia, melonggarkan pakaian pasien, menganjurkan ibu pasien untuk memberikan cairal oral (ASI, susu dan air putih), menganjurkan ibu pasien untk mengkompres hangat terhadap anaknya, memberikan obat oral yusimox syrup 3x 2,5 ml dan tramol syrup 3x 2,5 ml, mengukur tanda-tanda vital, respon yang didapatkan ibu pasien mengatakan anaknya masih demam dengan suhu tubuh $37,8^{\circ} \mathrm{C}$, akral hangat, kulit pasien kemerahan.

Implementasi hari kedua dilakukan pada Rabu, 3 Februari 2021 yaitu mengukur suhu tubuh dengan menggunakan termometer axilia, menganjurkan ibu pasien untuk mengganti pakaian anaknya dengan pakaian yang tipis mudah menyerap keringat, melakukan water tepid sponge, mengukur tanda tanda vital, dengan respon ibu pasien mengatakan anaknya masih demam, susah tidur, suhu $37^{\circ} \mathrm{C}$, akral hangat, kulit kemerahan, dan pasien rewel.

Implementasi hari ketiga dilakukan pada Kamis, 4 Februari 2021 yaitu, mengukur tanda tanda vital, mengukur suhu tubuh dengan menggunakan termometer axilia, menganjurkan ibu pasien untuk melakukan water tepid sponge pada anaknya ketika mengalami demam, respon yang didapatkan yaitu ibu pasien mengatakan anaknya sudah tidak demam dengan suhu tubuh $36,6^{\circ} \mathrm{C}$, pasien lebih tenang dan ceria. Evaluasi dilakukan oleh penulis setiap hari setelah tindakan keperawatan diberikan. Evaluasi pertama dilakukan pada Selasa, 2 Februari 2021 dengan respon subjektif ibu pasien mengatakan demam. Respon subyektif yang 
didapatkan suhu tubuh $38.4^{\circ} \mathrm{C}$, akral hangat, kulit pasien kemerahan. Evaluasi hari kedua dilakukan pada Rabu, 3 Februari 2021 dengan respon subyektif ibu pasien mengatakan anaknya masih demam. Respon obyektif suhu tubuh $37 \mathrm{oC}$, RR 22x /menit, Nadi 120 x /menit, akral hangat, pasien rewel. Evaluasi hari ketiga dilakukan pada Kamis, 4 Februari 2021 dengan respon subyektif ibu pasien menagatakan anaknya sudah tidak demam. Respon obyektif suhu tubuh $36.6 \mathrm{oC}$, RR $22 x /$ menit, Nadi 118x/menit, pasien lebih tenang dan tidak rewel. Hipertermi yang dialami oleh pasien dapat teratasi dengan intervensi yang sudah disusun sebelumnya dan membutuhkan waktu 3 hari kelolaan.

\section{PEMBAHASAN}

Pengkajian dilakukan dengan metode allowanamnesa, dengan hasil suhu tubuh $38,4^{\circ} \mathrm{C}$ yang berarti pasien mengalami demam. Demam adalah peningkatan suhu tubuh diatas normal (Zein, 2012). Menurut Labir, Sulisnadewi, \& Mamuaya (2014) kulit memerah ketika demam diakibatkan oleh mekanisme alamiah yang diatur oleh tubuh dimana pembuluh darah melebar dengan tujuan meningkatkan suhu permukaan kulit dan mengaktifkan kelenjar keringat. Gejala lain yang dialami pasien yaitu akral hangat ini dikarenakan perpindahan energi akibat perubahan suhu, aliran darah yang diatur saraf pusat memiliki peran penting dalam mendistribusikan panas sehingga kulit terasa hangat (Atik, 2013).

Hasil pemeriksaan laboratorium pasien didapatkan nilai monosit sebesar 6,8 dengan nilai normal 1-6, yang artinya pasien mempunyai kadar monosit dalam tubuh yang tinggi. Monosit adalah salah satu jenis sel darah putih yang berfungsi untuk melawan beberapa jenis infeksi, menyingkirkan sel dan jaringan rusak, serta meningkatkan kekebalan tubuh terhadap benda asing, jika jumlah monosit terlalu tinggi maka ini bisa menjadi indikator dari suatu gangguan kesehatan (Noya, 2019).

Penulis merumuskan diagnosa yang muncul pada pasien dengan kejang demam sederhana dan menegakkan prioritas masalah keperawatan yaitu hipertermi berhubungan dengan proses penyakit. Hipertermi adalah kondisi ketika suhu tubuh terlalu tinggi yang disebabkan oleh kegagalan sistem regulasi (Pane, 2020). Proses penyakit yang dialami oleh pasien hipertermi disebabkan adanya perubahan pada pusat panas di hipotalamus yang menyerang system tubuh, selain itu demam mungkin berperan dalam meningkatkan perkembangan imunitas spesifik dan non spesifik dalam membantu pemulihan atau pertahanan terhadap infeksi (Wardiyah, Setiawati, \& Romayati., 2016).

Intervensi yang penulis gunakan untuk mengatasi masalah hipertermi yang dialami pasien dapat teratasi dengan manajemen hipertermi yaitu mengidentifikasi dan mengelola peningkatan suhu tubuh sehingga nilai suhu tubuh kembali normal (PPNI, 2018).

Implementasi keperawatan menurut Wiratama (2019) yaitu pengelolaan atau perwujudan dari rencana keperawatan yang telah disusun pada tahap perencanaan. Implementasi pertama yang dilakukan oleh penulis adalah mengukur suhu tubuh dan tandatanda vital. Menurut Biotech, Pipiet \& Yohanes (2016) memantau suhu 
tubuh dan tanda-tanda vital ini bertujuan untuk mengidentifikasi adanya masalah kesehatan yang akut dan mengetahui secara cepat derajat kesakitan pasien.

Implementasi kedua yang dilakukan yaitu mengkaji penyebab hipertermi. Kejang demam adalah bangkitan kejang yang terjadi karena kenaikan suhu tubuh (suhu rectal diatas $38^{\circ} \mathrm{C}$ ) yang disebabkan oleh suatu proses ekstrakranium (Vebriasa, Herini, \& Triasih, 2016)

Implementasi ketiga yang dilakukan yaitu melonggarkan pakaian atau memakai pakaian tipis, menganjurkan memakai pakaian tipis mampu mengurangi penguapan dan membantu proses penyerapan keringat, ketika suhu tubuh tinggi maka tubuh akan merespon dengan mengeluarkan keringat dan menguap, selain itu memakai pakaian tipis juga dapat melindungi permukaan tubuh terhadap lingkungan dengan suhu udara yang tinggi atau panas (Sodikin, 2012).

Implementasi keempat yaitu berikan cairan oral dengan menganjurkan ibu pasien untuk memenuhi kebutuhan cairan anak selama sakit untuk membantu penurunan suhu tubuh. Salah satu hal yang mempengaruhi kebutuhan cairan adalah demam, dimana setiap suhu tubuh meningkat $1^{\circ} \mathrm{C}$ kebutuhan cairan juga ikut meningkat sebesar 12\% (Salam, 2016).

Implementasi yang kelima yaitu lakukan pendinginan eksternal dengan melakukan water tepid sponge. Menurut Haryani, Adimayanti, \& Astuti (2018) pada proses pemberian kompres tersebut memberikan efek adanya penyaluran sinyal hipotalamus melalui keringat dan dan vasodilatasi perifer sehingga proses perpindahan panas yang diperoleh dari kompres tepid sponge ini berlangsung melalui dua proses yaitu konduksi dan evaporasi.

Implementasi keenam yaitu anjurkan pasien untuk tirah baring. Tirah baring dilakukan pada pasien yang membutuhkan perawatan akibat penyakit atau kondisi tertentu untuk mengurangi aktivitas yang membuat kondisi pasien semakin buruk (Rahmasari \& Lestari, 2018).

Implementasi yang ketujuh yaitu kolaborasi dengan bidan terkait pemberian obat antipiretik dan antibiotik. Pasien mendapatkan terapi obat dari bidan yaitu yusimox syrup 3 $\mathrm{x} 2,5 \mathrm{ml}$ per oral, setiap $5 \mathrm{ml}$ mengandung amoxicillin 143,49 mg $(125 \mathrm{mg})$ dilarutkan dalam $51 \mathrm{ml}$ air mineral, dan tramol syrup $3 \times 2,5 \mathrm{ml}$ per oral, setiap $5 \mathrm{ml}$ mengandung paracetamol $120 \mathrm{mg}$ dan alkohol 4,8 $\%$. Tramol merupakan salah satu obat golongan antipiretik pada anak.

Evaluasi dilakukan pada Kamis, 4 Februari 2021 setelah 3 hari proses keperawatan yang telah dilakukan yaitu masalah hipertermi pada pasien sudah teratasi. Ditunjukkan dengan kembalinya suhu tubuh pasien ke batas normal serta respon pasien yang tampak lebih tenang, ceria, dan tidak tampak kemerahan pada kulit.

\section{SIMPULAN}

Masalah keperawatan hipertermi b/d proses penyakit dapat teratasi dengan 3 hari pengelolaan dengan kriteria hasil kulit kemerahan dari nilai 2 menjadi 5, suhu tubuh dari nilai 2 mejadi 5, takikardi dari nilai 2 menjadi 5, suhu kulit dari nilai 2 mejadi 5. Respon pasien selama pengelolaan yaitu suhu tubuh pasien $36,6^{\circ} \mathrm{C}$, RR $22 x /$ menit, nadi $118 \mathrm{x} /$ menit, pasien lebih tenang dan tidak rewel. Saran bagi keluarga 
pasien yaitu dapat mengetahui bagaimana menangani demam pada anak dan mampu mencegah terjadinya kejang berulang.

\section{DAFTAR PUSTAKA}

Atik, Y. (2013). Buku Tanda dan Gejala Hipertermi. Jakarta: EGC.

Awaluddin, \& Dkk. (2017). Hubungan Status Gizi dengan Hasil Belajar Siswa Kelas 1 SD Negeri 5 Banda Aceh. Jurnal Pesona Dasar, 5(2). Retrieved from www.jurnal.unsyiah.ac.id

Biotech, Pipiet, Yohanes. (2016). Modul Keterampilan Klinik Dasar Blok 5. https://respiratory.unej.ac.id. Diakes pada tanggal 3 Juni 2021

Deliana, M. (2016). Tata Laksana Kejang Demam pada Anak. Sari Pediatri, 4(2), 59. https://doi.org/10.14238/sp4. 2.2002.59-62

Esyuananik. (2016). Asuhan Kebidanan Neonatus, Bayi, Balita dan Anak Pra Sekolah. Kementrian Kesehatan Republik Indonesia. http://bppsdmk.kemkes.go.id/ pusdiksdmk/wpcontent/uploa ds/2017/08/Asuhan-

Kebidanan-Neonatus-Bayi-

Balita-dan-Apras-

Komprehensif.pdf. Diunduh pada 18 maret 202122.45 WIB.

Haryani, S., Adimayanti, E., \& Astuti, A. P. (2018). Pengaruh Tepid
Sponge Terhadap Penurunan Suhu Tubuh Pada Anak Pra Sekolah Yang Mengalami Demam Di Rsud Ungaran. Jurnal Keperawatan Dan Kesehatan Masyarakat Cendekia Utama, 7(1), 44. https://doi.org/10.31596/jcu.v 0i0.212. Diunduh pada 9 Maret 2021 19.40 WIB

Hidayat, A.A. (2012). Riset Keperawatan dan Teknik Penulisan Ilmiah. Salemba Medika. Edisi 2

Indijah Sujat Woro \& Fajri Purnama. Modul Bahan Ajar Farmakologi. Jakarta: Kemenkes

Kemenkes RI. (2019). Profil kesehatan indonesia 2018 (indonesia health profile 2018).

Http://www.depkes.go.id/reso urces/download/pusdatin/prof il-kesehatan-indonesia /Datadan-informasi_Profilkesehatan-Indonesia2018.pdf. Diunduh pada 18 maret 2021 pukul 20.00 WIB

Labir, Ketut., Sulisnadewi., Mamuaya, Silvana. (2014). Pertolongan Pertama dengan Kejang Demam pada Anak. Artikel Ketut Labir dkk,2.pdf.

Noya, Allert Benedicto Leuan. (2019). Memahami Berbagai Penyebab Monosit Tinggi. Alodokter. Diakses pada 26 juni 2021 pukul 14.46 WIB https://www.alodokter.com/m emahami-berbagai-penyebabmonosit-tinggi 
Pane, Mare Dame Cristy. (2020). Hipertermia. Alodokter. Diakses pada 9 Juni 2021 pukul $22.32 \quad$ WIB. https://www.alodokter.com/hi pertermia

PPNI. (2018). Standar Intervensi Keperawatan Indonesia Definisi dan Tindakan Keperawatan. Jakarta: Dewan Pengurus Pusat Persatuan Perawat Nasional Indonesia.

PPNI. (2017). Standar Diagnosa Keperawatan Indonesia Definisi dan Indikator Diagnostik. Jakarta: Dewan Pengurus Pusat Persatuan Perawat Nasional Indonesia.

Sodikin. (2012). Prinsip Perawatan Demam Pada Anak. Yogyakarta: Pustaka Belajar

Supartini, Yupi. (2014). Buku Ajar Konsep Keperawatan Dasar Anak. Jakarta: Penerbit Buku Kedokteran EGC

Vebriasa, A., Herini, E. S., \& Triasih, R. (2016). Hubungan antara Riwayat Kejang pada Keluarga dengan Tipe Kejang Demam dan Usia Saat Kejang Demam Pertama. Sari Pediatri, 15(3), 137. Diunduh pada 1 Juni 2021. https://doi.org/10.14238/sp15 .3.2013.137-40

Wardiyah, A., Setiawati, \& Romayati, U. (2016). Perbandingan Efektifitas Pemberian Kompres Hangat Dan Tepid Sponge Terhadap Penurunan Suhu Tubuh Anak Yang Mengalami Demam Di Ruang Alamanda Rsud Dr . H . Abdul Moeloek. Jurnal Kesehatan Holistik, 10(1), 36-44. Diunduh pada 1 Juni 2021.

https://www.ejournal.unper.a c.id/index.php /PHARMACOSCRIPT/articl e/view/105

Wiratama, P. (2019). LangkahLangkah Yang Tepat Dalam Pelaksanaan Proses Keperawata. Dimuat dalam https://osf.io/preprints/inarxiv /8q3uw/. Diakses pada tanggal 1 Juni 2021 Pukul 15.30 WIB.

Wong D. L. 2012. Pedoman Klinis Keperawatan Pediatrik. Alih bahasa Monic Ester. Edisi 4. Jakarta: EGC.

Zein, U. (2012). Buku saku (Issue 48, pp. 1-2). Diunduh pada 3 Juni 2021.

https://penelitian.uisu.ac.id/w pcontent/uploads/2020/03/14 -buku-demam.pdf 